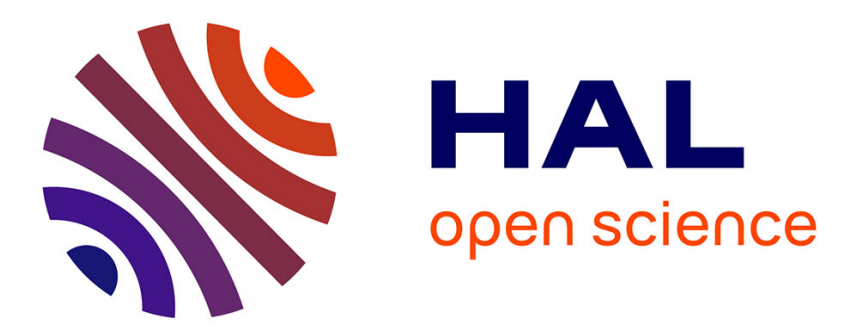

\title{
Effect of Cortisol on Aquaporin Expression in the Esophagus of the European Eel, Anguilla anguilla
}

Anne-Sophie Martinez, Gillian Wilson, Claire Phillips, Christopher Cutler, Neil Hazon, Gordon Cramb

\section{To cite this version:}

Anne-Sophie Martinez, Gillian Wilson, Claire Phillips, Christopher Cutler, Neil Hazon, et al.. Effect of Cortisol on Aquaporin Expression in the Esophagus of the European Eel, Anguilla anguilla. Annals of the New York Academy of Sciences, 2005, Trends in Comparative Endocrinology and Neurobiology, 1040 (1), pp.395-398. 10.1196/annals.1327.072 . hal-02550684

\section{HAL Id: hal-02550684 \\ https://hal.science/hal-02550684}

Submitted on 22 Apr 2020

HAL is a multi-disciplinary open access archive for the deposit and dissemination of scientific research documents, whether they are published or not. The documents may come from teaching and research institutions in France or abroad, or from public or private research centers.
L'archive ouverte pluridisciplinaire HAL, est destinée au dépôt et à la diffusion de documents scientifiques de niveau recherche, publiés ou non, émanant des établissements d'enseignement et de recherche français ou étrangers, des laboratoires publics ou privés. 


\title{
Effect of Cortisol on Aquaporin Expression in the Esophagus of the European Eel, Anguilla anguilla
}

\author{
ANNE-SOPHIE MARTINEZ, GILLIAN WILSON, CLAIRE PHILLIPS, \\ CHRISTOPHER CUTLER, NEIL HAZON, AND GORDON CRAMB \\ LBBM, Université de Caen, Caen, France, and School of Biology, \\ University of Saint Andrews, Saint Andrews, United Kingdom
}

\begin{abstract}
Long-term cortisol infusion into freshwater (FW)-adapted eels induced a significant increase in aquaporin-1 (AQP1) mRNA expression within the esophageal epithelium of migratory "silver" eels, but not in nonmigratory, immature "yellow" eels. Cortisol treatment had no significant effect on the mRNA abundance of a second aquaporin-1 isoform, termed AQP1dup, which exhibited a highly variable expression profile among individual members of all fish groups. These results suggest that cortisol, at plasma concentrations similar to that found during FW/seawater (SW) acclimation, induces upregulation in AQP1 expression and thus increases esophageal water permeability during the migration of eels to the SW environment.
\end{abstract}

KEYWORDS: European eel; aquaporin; cortisol; esophagus; seawater (SW) acclimation

\section{INTRODUCTION}

Sodium absorption across the esophageal epithelia is considered to be the first step in the desalination of imbibed seawater (SW) in marine teleosts. ${ }^{1}$ Therefore, this tissue plays a major role in osmoregulation in SW in both stenohaline marine and euryhaline teleosts, such as the European eel (Anguilla anguilla). Because the esophagus has also been reported to have low water permeability in marine fish, ${ }^{2}$ the recent discovery of aquaporin (AQP) water channels in this tissue ${ }^{3}$ has led to ambiguity as to its physiological role in osmoregulation. Hormonal actions on ion and water transport across intestinal, renal, and branchial epithelia are fundamental to body fluid homeostasis during the course of adaptation to different salinities; however, almost all studies to date have focused on the movement of ions. ${ }^{4}$ In this study, we report the effects of an infusion of cortisol (the major corticosteroid released by the interrenal gland) on mRNA levels for two aquaporin-1 isoforms (termed AQP1 and AQP1dup) in the esophagus of "silver" and "yellow" life stages of the European eel.

Address for correspondence: Anne-Sophie Martinez, LBBM, Université de Caen, Esplanade de la Paix, 14032 Caen Cedex, France. Voice: +33-0-2-31-56-52-94; fax: +33-0-2-31-56-53-46. am102@st-andrews.ac.uk

Ann. N.Y. Acad. Sci. 1040: 1-4 (2005). () 2005 New York Academy of Sciences. doi: 10.1196/annals.1327.072

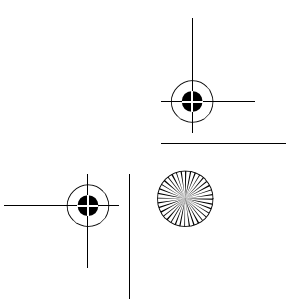




\section{MATERIALS AND METHODS}

Salinity transfers, RNA extraction, cloning, sequencing, Northern blotting, and quantitative and statistical analyses were performed as previously described by Cutler and Cramb. ${ }^{5}$ Freshwater (FW) eels were anesthetized (48 ppm MS222, 3-aminobenzoic acid ethyl ester) and implanted with Alzet mini osmotic pumps, releasing either the vehicle (a 30\% solution of 2-hydroxypropyl- $\beta$-cyclodextrin in control animals) or cortisol dissolved in the vehicle at a rate of $15 \mu \mathrm{g} / \mathrm{kg}$ body weight per hour for 7 days. Individual mRNA abundance was expressed as cpm/ $\mu \mathrm{g}$ total RNA after first correcting for the relative amounts of total RNA loaded for each sample by quantification of the combined $18 \mathrm{~S}$ and $28 \mathrm{~S}$ ribosomal RNAs in each lane, as described previously. ${ }^{6}$

\section{RESULTS AND DISCUSSION}

AQP1 and to a lesser extent AQP1dup mRNAs were highly expressed in the esophageal epithelium of FW-adapted control yellow and silver eels (FIG. 1). AQP1dup expression exhibited marked variability among individual eels, with some fish exhibiting no detectable expression at all. Although reports have suggested only a small net osmotic water movement across the esophagus, ${ }^{2}$ unidirectional fluxes were not measured, leaving open the possibility of larger (nearly equivalent) unidirectional fluxes across this epithelium. The possibility of increased water permeabilities has been suggested by Parmelee and Renfro ${ }^{1}$ and by Lignot et al. ${ }^{3}$ who described the expression of three AQP water-channel proteins within the eel esophagus.

In teleost fish, cortisol has been identified largely as an SW-adapting hormone, primarily promoting SW-adapting mechanisms. ${ }^{5}$ The transfer of eels into SW induces a transient increase in circulating cortisol concentrations. This increase is not sustained, however, and concentrations gradually fall after 3-7 days to levels similar to those seen in FW-adapted fish. ${ }^{7,8}$ When administered to FW-adapted eels, the steroid has been shown to induce epithelial features similar to those of SW eels, including an increase of the permeability of ions in the esophagus and the intestine. ${ }^{4}$ Cortisol infusion in FW-adapted eels induced a $100 \%$ increase in the expression of the AQP1 isoform in the silver eel, but not in the yellow eel esophagus. Cortisol also failed to induce any significant change in AQP1dup mRNA expression within the esophagus of either yellow or silver eels (FIG. 1).

Our results suggest that AQP1 and AQP1dup are expressed in the esophagus during both adult life stages of the European eel. They also imply that cortisol treatment upregulates AQP1 (but not AQP1dup) mRNA expression, although only in the silver eels. It thus seems possible that unknown developmental changes in the physiology of migratory silver eels are responsible for the increased sensitivity of the esophagus to cortisol and/or the induction of AQP1 gene expression by this hormone.

Although exhibiting a highly variable expression profile across all animals tested, the AQP1dup isoform may be concerned primarily with cell-volume homeostasis rather than vectoral water transport involved in the osmoregulatory adapting mechanisms. Hence, depending on their cellular and subcellular locations, these AQP1 isoforms might have a role in the following: (i) in water trafficking associated with mucus secretion or maintenance of "wetness", as speculated by Lignot et al.; 

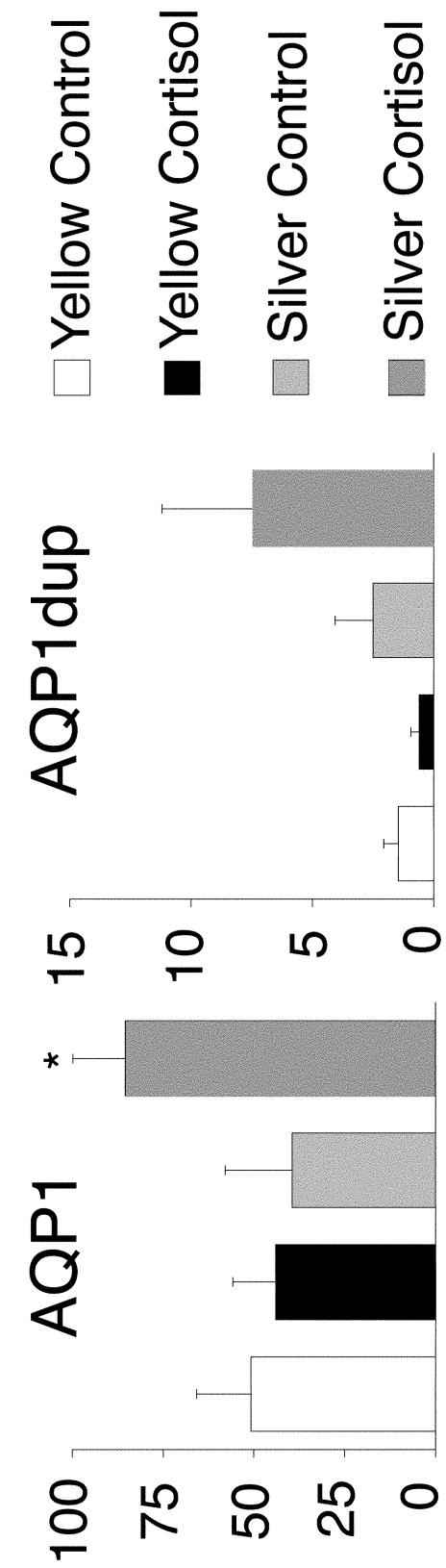

$\forall N Y$ [E]O] 6n' / $\forall N Y$ W WdO
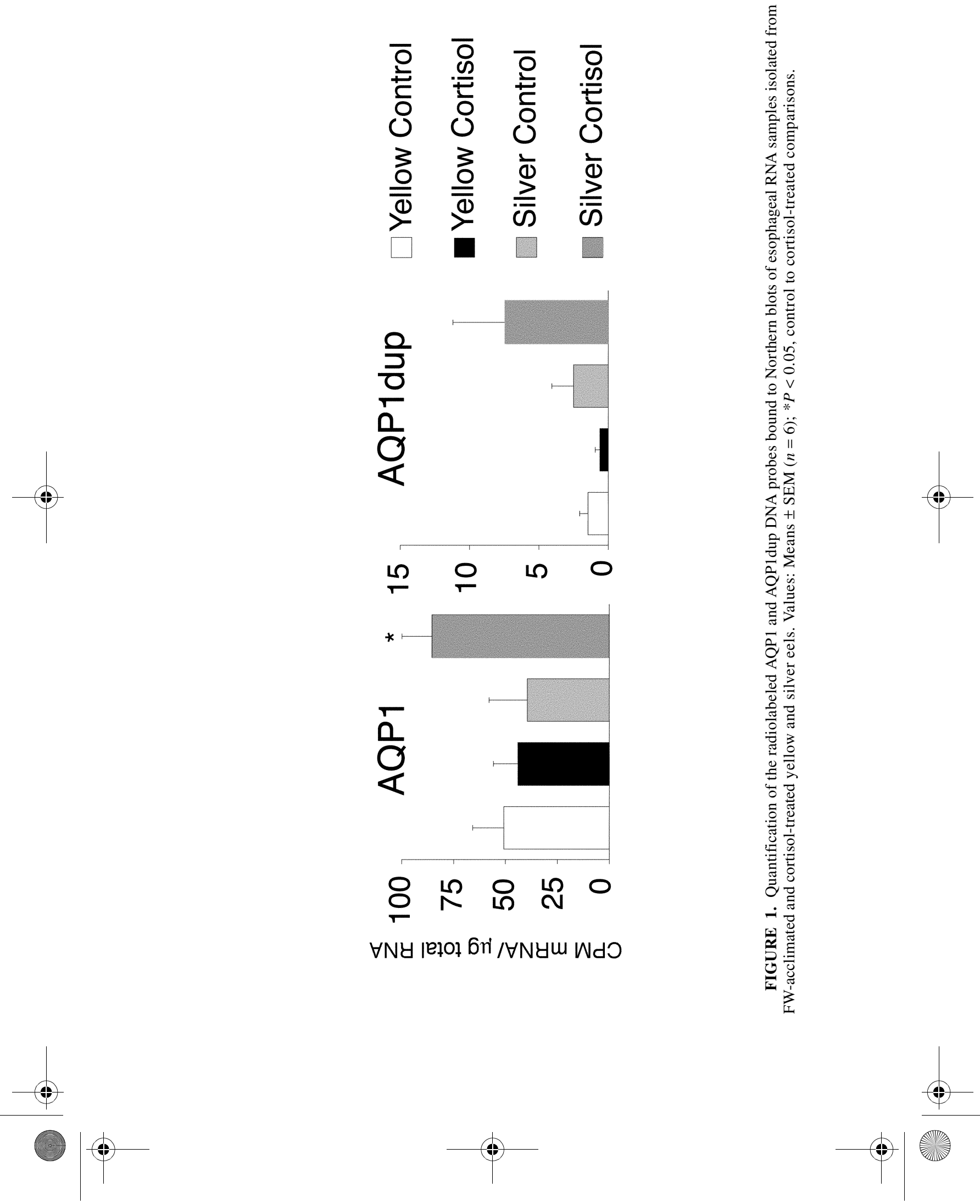
(ii) in passive transcellular water fluxes from or to the luminal fluid imbibed in FW or SW medium; and/or (iii) in the protection of epithelial cells from the effects of swelling or shrinkage due to water infiltration from or to the lumen fluid.

\section{REFERENCES}

1. Parmelee, J.T. \& J.L. Renfro. 1983. Esophageal desalination of seawater in flounder: role of active sodium transport. Am. J. Physiol. 245: R888-R893.

2. Nagashima, K. \& M. ANDO. 1993. Characterization of esophageal desalination in the seawater eel, A. japonica. J. Comp. Physiol. 164: 47-54.

3. Lignot, J.H., C.P. CutLer, N. HAZON \& G. CRAMB. 2002. Water transport and aquaporins in the European eel. In Osmoregulation and Drinking in Vertebrates. Vol. 54, pp. 4959. SEB Symp. Series. Sci. Pub. Oxford.

4. Hazon, N. \& R.J. Balment. 1998. Endocrinology. In The Physiology of Fishes, pp. 441-463. Marine Science Series, CRC Press. Boca Raton, FL.

5. Cutler, C.P. \& G. CRAMB. 2002. Branchial expression of an aquaporin 3 (AQP-3) homologue is downregulated in the European eel Anguilla anguilla following seawater acclimation. J. Exp. Biol. 205: 2643-2651.

6. Cutler, C.P., S. Brezillon, S. BeKIR et al. 2000. Expression of a duplicate $\mathrm{Na}+\mathrm{K}+-$ ATPase $\beta 1$ isoform in the European eel (Anguilla anguilla). Am. J. Physiol. 279: R222-R229.

7. Ball, J.N., I. Chester-Jones, M.E. Forster et al. 1971. Measurement of plasma cortisol levels in the eel, Anguilla anguilla, in relation to osmotic adjustments. J. Endocrinol. 50: $75-96$.

8. Forrest, J.N., JR., W.C. MacKay, B. Gallagher \& F.H. Epstein. 1973. Plasma cortisol response to saltwater adaptation in the American eel Anguilla rostrata. Am. J. Physiol. 224: 714-717. 